Bond University

Research Repository

\title{
Sodium Intake Beliefs, Information Sources, and Intended Practices of Endurance Athletes Before and During Exercise
}

\author{
McCubbin, Alan J; Cox, Gregory R; Costa, Ricardo J S \\ Published in: \\ International Journal of Sport Nutrition and Exercise Metabolism
}

DOI:

10.1123/ijsnem.2018-0270

Licence:

Unspecified

Link to output in Bond University research repository.

Recommended citation(APA):

McCubbin, A. J., Cox, G. R., \& Costa, R. J. S. (2019). Sodium Intake Beliefs, Information Sources, and Intended Practices of Endurance Athletes Before and During Exercise. International Journal of Sport Nutrition and Exercise Metabolism, 29(4), 1-11. https://doi.org/10.1123/ijsnem.2018-0270

\section{General rights}

Copyright and moral rights for the publications made accessible in the public portal are retained by the authors and/or other copyright owners and it is a condition of accessing publications that users recognise and abide by the legal requirements associated with these rights.

For more information, or if you believe that this document breaches copyright, please contact the Bond University research repository coordinator. 


\section{INTER NATIONAL JOURNAL OF \\ SPORT NUTRITION and EXERCISE METABOLISM}

Sodium intake beliefs, information sources and intended practices of endurance athletes before and during exercise

\begin{tabular}{|r|l|}
\hline Journal: & International Journal of Sport Nutrition \& Exercise Metabolism \\
\hline Manuscript ID & IJSNEM.2018-0270.R2 \\
\hline Manuscript Type: & Original Research \\
\hline Keywords: & Endurance athletes, Sodium intake, Hydration status \\
\hline \multicolumn{2}{|l}{} \\
\end{tabular}

\section{SCHOLARONE Manuscripts}




\section{Abstract}

2 There is little information describing how endurance athletes perceive sodium intake in relation to

3 training and competition. Using an online questionnaire, this study assessed the beliefs, information sources and intended practices regarding sodium ingestion for training and competition. Endurance athletes $(n=344)$ from six English-speaking countries completed the questionnaire and were included

6 for analysis. The most cited information sources were social supports (63\%), self-experimentation

$7 \quad(56 \%)$ and media (48\%). Respondents generally believed ( $>50 \%$ on electronic Visual Analogue Scale

8 (VAS)) endurance athletes require additional sodium on a daily basis (median 67\% (IQR 40-81\%)),

9 benefit from increased sodium in the days preceding competition $(60 \%(30-77 \%))$, should replace sodium losses during training (69\% (48-83\%)) and competition (74\% (54-87\%)), and would benefit

11 from sweat composition testing (82\% (65-95\%)). Respondents generally believed sodium ingestion

12 during endurance exercise prevents exercise-associated muscle cramps (75\% (60-88\%)) and exerciseassociated hyponatraemia (74\% (62-89\%)). The majority (58\%) planned to consciously increase sodium or total food intake (i.e. indirectly increasing sodium intake) in the days preceding competition. Most (79\%) were conscious of sodium intake during competition, but only $29 \%$ could articulate a specific intake plan. A small minority (5\%) reported using commercial sweat testing services, of which $75 \%$ believed it was beneficial. We conclude that endurance athletes commonly perceive sodium intake as important for their sporting activities. Many intend to consciously increase sodium intake in the days preceding and during competition, although these views appear informed mostly by non-scientific and/or non-evidence-based sources. 


\section{Introduction}

During endurance exercise, muscular contractions produce heat, resulting in sweating to support thermoregulation (Sawka et al., 2007). Considering sodium is the most abundant electrolyte present in sweat, prolonged heavy sweating can cause significant sodium losses (Baker, 2017). Whilst this is broadly reflected in sport and exercise nutrition guidelines, specific sodium recommendations for athletes are lacking (Shirreffs \& Sawka, 2011; Thomas et al., 2016). Despite this, numerous businesses offer sweat composition testing, which combined with purpose-built sodium supplements allow quantifiable sodium replacement. Endurance athletes commonly believe sodium intake improves performance and prevents health consequences of endurance exercise, including exerciseassociated muscle cramps (EAMC) and exercise-associated hyponatraemia (EAH) (Winger et al. 2011; Winger et al., 2013). Mechanisms cited include enhanced fluid absorption, maintenance of total body water, plasma volume and circulating sodium concentration (Sawka et al., 2007).

Despite this theoretical rationale, evidence that sodium replacement during exercise improves performance is scarce. A recent systematic literature review (SLR) found minimal evidence of performance benefits from sodium intake during exercise (2-13 $\mathrm{h}$ duration), although it was noted the quality of existing studies were poor (McCubbin \& Costa, 2018a). In contrast, pre-exercise sodium loading (1500-3000 mg ingested 15-45 min prior to exercise stress) appears beneficial to performance during 1-2 h exercise durations due to expanded plasma volume, resulting in improved thermoregulation (Coles \& Luetkemeier, 2005; Sims et al., 2007). In addition to performance, sodium replacement during endurance exercise may play a role in the prevention and/or management of negative exercise-associated health outcomes. The role of sodium in EAMC remains controversial, although the prevailing view is that neuromuscular fatigue is the more likely cause (Schwellnus, 2009). Sodium intake during exercise can influence serum sodium concentration, although not to the same extent as fluid intake (Hew-Butler et al., 2015). It has been suggested that significant unreplaced sodium losses may contribute to asymptomatic (Noakes et al., 2005; Hoffman et al., 2013) and in some cases symptomatic (Lewis et al., 2018) hypovolaemic EAH, representing a possible rationale for 
51 sodium ingestion during prolonged exercise (Hew-Butler et al., 2015). It has also been suggested

52 sodium losses during ultra-endurance exercise may influence bone mineral content, through sodium resorption to maintain circulating concentrations (Hew-Butler et al. 2013), although implications for bone health are yet to be determined.

Whilst previous studies have investigated beliefs and strategies for sodium ingestion during endurance events (Costa et al., 2014; Costa et al., 2013; Hoffman \& Stuempfle, 2014; Pfeiffer et al., 2012;

Winger et al., 2013), little is known about how endurance athletes perceive the role of sodium in relation to training, before and after competition. With this in mind, the purpose of this exploratory study was to observe beliefs, information sources and intended practices of endurance athletes regarding sodium for training and competition. Based on anecdotal evidence, we hypothesised endurance athletes would; a) perceive increased daily sodium requirements; b) believe sodium ingestion during exercise improves endurance performance and reduces EAMC and EAH risk; c) plan to increase sodium intake 2-3 days before competition, and; d) deliberately ingest foods, fluids and supplements during competition for their sodium content.

Methods

This descriptive, cross sectional study, utilised an online questionnaire developed based on the principles of Desbrow and Leveritt (2007). The questionnaire was circulated internationally via email and social media, available in English. Respondents were endurance athletes $\geq 18$ years of age, of any competitive level, intending to compete in endurance events $\geq 2 \mathrm{~h}$ duration in the following six months. number 12241). 
The questionnaire was conducted using Qualtrics (Provo, Utah, USA), an online platform for questionnaire design, distribution and analysis that is well-established for exploratory research in health care settings (Ogbogu \& Necyk, 2016; Yoon et al. 2018). The questionnaire included five sections as described below. Refer to Appendix 1 for the questionnaire in full.

Sodium Information Sources: Participants were asked to identify the information sources that had influenced their sodium intake in respect to training and competition. These included advice from health professionals, sport-specific (coaches, managers, and trainers) and social supports (fellow athletes, friends and relatives), peer reviewed journals, media (television, magazines, internet, etc.), self-experimentation, sales and marketing (advertising material, company sales representatives and store attendants).

Sodium Beliefs: Two sets of questions investigated the beliefs of endurance athletes regarding the consumption of sodium before and during endurance exercise. The first set asked participants to indicate, using an electronic visual analogue scale (VAS), to what extent they agreed with statements regarding a specific need for athletes to consume more sodium day-to-day, before, during and after training and competition, and if measurement of sodium losses would be beneficial for endurance athletes. The second section asked participants to indicate to what extent they agreed that increased sodium intake would be beneficial for aspects of health (i.e., EAMC, EAH) and performance during endurance exercise, using the same VAS. In both sections the VAS ranged from $0 \%$ (strongly disagree) to $100 \%$ (strongly agree). An electronic slider commenced in the midway $(50 \%) \mathrm{mm}$ position (neither agree or disagree), and results only recorded if the participant clicked on the slider, to prevent data being recorded as $50 \%$ due to failure to answer the question.

Intended Practices: Participants were asked to indicate whether they were consciously aware of the amount of sodium they consume in the days preceding competition. If so, they were then asked over what time period, and whether they deliberately planned to increase, reduce or maintain sodium intake compared to their usual day-to-day intake. They were asked to identify the foods, fluids and supplements used to achieve a specific sodium intake in preparation for competition. All participants were also asked whether they planned to change their overall food and fluid intake, regardless of 


\section{Results}

sodium, compared to usual intake. A second section asked participants to identify if they were consciously aware of their sodium intake during competition, and if so, if they identified a specific amount to consume. They were also asked what foods, fluid and supplements they intended to consume during a race, specifically for their sodium content.

Sweat Composition Testing: Participants were asked if they had previously had their sweat composition tested using commercial testing services (i.e., excluding research studies). Participants who had undertaken sweat testing were then asked their motivations for doing so, how the results were applied to their nutrition planning, and whether in hindsight they felt that the testing had achieved the goals they had for completing the test in the first place.

\section{Statistical Analysis}

Data are presented as median (inter-quartile range, IQR) based on distribution, which was assessed using the Kolmogorov-Smirnov test. Effects of sex, geographical region and competitive level on responses were analysed. For continuous variables, sex differences were analysed using the MannWhitney U test, differences by region and competitive level were analysed using the Kruskal-Wallis analysis of variance by ranks, with significant outcomes analysed using the Mann-Whitney U test to determine between-group differences. For categorical data, sex, region and competitive level effects were assessed using chi-square analysis, with categories collapsed when more than $20 \%$ of cells had an expected count of less than five. Where associations were found, post-hoc analysis was performed through two by two chi square tables for all category combinations. Analysis was performed using SPSS 24.0 (IBM Corp., Armonk, New York, USA) with significance accepted at $p \leq 0.05$, except where adjusted as described.

\section{Demographics}


Three hundred and forty-four endurance athletes ( $n=199$ males, $n=145$ females) from Australia and New Zealand (60.0\%), North America (26.5\%) and the United Kingdom (UK) and Ireland (7.7\%) completed the questionnaire (see Table 1). A small number of respondents $(\mathrm{n}=22)$ resided elsewhere but were excluded to allow regional comparisons. Respondents were predominately competitive agegroup athletes $(66 \%)$, of which most $(79 \%)$ mainly compete in events longer than marathon (running) or Olympic distance (triathlon), or three hours in other sports. Sports included distance running, race walking, triathlon, cycling, mountain biking, open-water swimming, adventure racing, orienteering, endurance rowing, canoeing and kayaking, endurance winter sports and ocean sailing.

\section{Information Sources}

Reported information sources are shown in Table 2 - the average number cited was 3.7 per participant. Social supports (particularly fellow athletes) were most cited (63\%), followed by selfexperimentation (56\%), media (48\%), health professionals (38\%) and sport-specific supports (35\%).

Males indicated greater media influence than females $\left(\chi^{2}=5.3, p<0.05\right)$, while less UK and Irish athletes sourced information from health professionals $\left(\chi^{2}=6.0, p=0.05\right)$ and sport-specific supports $\left(\chi^{2}=10.5, p<0.01\right)$ but more from media $\left(\chi^{2}=13.5, p<0.01\right)$. More professional and aspiring professionals sourced information from health practitioners $\left(\chi^{2}=7.4, p<0.05\right)$ and scientific sources (e.g. peer-reviewed journals) $\left(\chi^{2}=7.3, \mathrm{p}<0.05\right)$ compared to lower competitive levels.

\section{Sodium Beliefs}

Agreement with statements about sodium for endurance athletes are shown in Figure 1. Respondents generally agreed ( $>50 \%$ on VAS) endurance athletes have increased daily sodium requirements (median 67\% (IQR 40-81\%)), would benefit from increasing sodium intake in the days preceding competition (60\% (30-77\%)), should replace sweat sodium losses during training (69\% (48-83\%)) and racing (74\% (54-87\%)), after training (75\% (59-88\%)) and racing (80\% (64-91\%)), and would benefit from sweat composition testing (82\% (65-95\%)) although individual responses varied markedly 
155 (Figure 1). There were no sex, region or competitive level differences. There was some agreement 156 that sodium intake during exercise improved physical endurance (65\% (52-77\%)), but less so speed 157 (54\% (50-69\%)), power (55\% (50-69\%)) and mental alertness (58\%, 50-71\%). Respondents generally agreed with statements that sodium intake helped prevent EAMC $(75 \%(60-88 \%))$ or reduce their severity (71\% (51-84\%)), and helped prevent EAH (74\% (62-89\%)), but with marked variation in individual responses (Figure 2). There was less agreement that sodium ingestion reduced core body temperature $(53 \%(50-71 \%))$, or prevented bone mineral loss during exercise $(53 \%(50-71 \%))$. No sex or competitive level differences were observed, however Australian and New Zealand athletes agreed more strongly $(\mathrm{p}<0.01)$ that sodium could prevent $(77 \%(62-89 \%))$ or treat $(73 \%(56-86 \%))$ EAMC compared to North American athletes (69\% (52-79\%) and 64\% (50-78\%) respectively).

Almost half (45\%) of respondents indicated being conscious of sodium intake in the days preceding competition, always or specifically for hot or longer events. Of these, $64 \%$ intended to increase, $33 \%$ maintain, and 3\% reduce sodium intake during this period. There were no sex, region or competitive level effects on intended sodium intake prior to competition. Most respondents (61\%) indicated they would be conscious of sodium intake 1-5 days preceding competition, $24 \%$ for less than 1 day and $15 \%$ for more than 5 days. There were no sex, region or competitive level effects.

Strategies to increase sodium intake prior to competition are shown in Table 3. Females were more likely to choose high sodium foods compared to males ( $p<0.05$ ), who were more likely to choose powdered sports and rehydration drinks $(\mathrm{p}<0.05)$. Australian and New Zealand athletes were less likely to add salt to food and fluids $(\mathrm{p}<0.05)$. There was no competitive level effect on foods chosen. Because overall food quantity may unintentionally influence sodium intake, participants were asked about overall food quantity in the days preceding competition. Almost half (41\%) indicated they intend to increase overall intake in the days preceding competition; only $3 \%$ would reduce during this 
period. A region effect was found $\left(\chi^{2}=13.6, \mathrm{p}<0.01\right)$, whereby Australian and New Zealand athletes were more likely to increase overall intake in the days preceding races $(\mathrm{p}<0.01)$, and North American athletes less likely $(\mathrm{p}<0.01)$. There were no sex or competitive level effects. Overall, $58 \%$ of respondents intend to consciously increase sodium intake, total food intake or both during this period.

\section{Intended Practices During Competition}

Most respondents (79\%) indicated being conscious of sodium intake during competition, an additional $6 \%$ if competing in longer events or in hot ambient conditions $\left(\geq 30^{\circ} \mathrm{C}\right)$. There were no sex or competitive level effects. However, there was a region effect $\left(\chi^{2}=8.470, p<0.05\right)$, whereby UK and Irish athletes were less likely to be conscious of sodium intake than North American or Australian and New Zealand athletes $(68 \%, 89 \%$ and $87 \%$ respectively, $p<0.01)$. Of those conscious of sodium intake, only $29 \%$ articulated specific plans for how much sodium they would consume, with no sex, region or competitive level effects. These respondents described either specific hourly sodium targets in milligrams, or quantified combinations of products. The foods and fluids athletes intend to consume during a race to obtain sodium were diverse, with some sex, region and competitive level effects (Table 4).

\section{Sweat Composition Testing}

Only 16 respondents (5\%) reported having sweat composition tested commercially (males $n=10$, females $n=6$ ). Motivations included a desire to improve competition performance (69\%), prevent EAMC (50\%), EAH (19\%), and general interest (19\%). Most (75\%) felt assessing sweat composition had been beneficial, $19 \%$ not beneficial and $6 \%$ unsure. Whilst the lack of responses prevented chisquare analyses, males were more likely than females to undertake sweat testing to improve performance ( $90 \%$ and $33 \%$, respectively), and more likely to believe testing had been beneficial ( $90 \%$ and $50 \%$, respectively). 
207

208

209

210

211

212

213

214

215

216

217

218

219

220

221

222

223

224

\section{Discussion}

The purpose of this study was to describe beliefs, information sources and intended practices of endurance athletes regarding sodium intake for training and competition. In agreement with our hypotheses, respondents; a) believe daily sodium requirements are increased due to exercise, and quantifying sweat sodium losses would be beneficial; b) believe sodium intake during exercise improves endurance performance, prevents and/or attenuates EAMC and EAH; c) plan to increase either sodium or total food intake in the 1-5 days before competition; and d) plan to consume a variety of products during competition for their sodium content, but do not usually have a specific plan for the amount of sodium to consume. In addition, respondents mostly obtain information about sodium from people without sport and exercise nutrition qualifications or expertise (i.e., fellow athletes, friends and relatives, the media or self-experimentation), and whilst less than $5 \%$ had undergone commercial sweat testing, the majority of these athletes believed it was worthwhile.

Few studies have previously examined the beliefs, information sources, intended or actual sodium intakes of endurance athletes, and most are limited to sodium ingestion during competition (White \& Hoffman, 2018; Hoffman \& Stuempfle, 2014; (Winger, Dugas, \& Dugas, 2011); Winger et al., 2013). In a recent questionnaire of ultramarathon runners, $85 \%$ believed salt tablets should be made available at races, with $65 \%$ and $58 \%$ of those stating that salt tablets prevent EAH and EAMC respectively. In addition, $43 \%$ stated that salt tablets aid hydration status White \& Hoffman, 2018). The prevalence of sodium supplementation, in addition to sodium-containing food and fluids, was $90 \%$ and $95 \%$ in questionnaire respondents competing in the 2011 and 2013 Western States Endurance Run, respectively (Hoffman \& Stuempfle, 2014; Winger et al., 2013). These data are consistent with our findings in athletes across a range of endurance sports, whereby median VAS scores indicated general agreement that sodium intake during endurance exercise prevented and/or attenuated EAMC and EAH. Furthermore, over $80 \%$ of respondents specifically considered sodium intake during competition either all the time or specifically in hot or long duration events. 
234 In contrast, we are not aware of any well-controlled studies that investigated intended practices or 235 quantified sodium intake in the days preceding endurance competition, compared to typical intake.

236 This is important because of a possible interaction between dietary sodium intake in the preceding 237 days and the sweat sodium concentration during exercise (McCubbin \& Costa, 2018b). The majority 238 of studies found in a recent SLR compared reduced dietary sodium to usual intake (McCubbin \& 239 Costa, 2018b), whereas the findings of the present study suggest the most likely change in sodium 240 intake in the days preceding competition is an increase. We were unable to quantify the extent of the 241 intended increase in sodium intake prior to competition. Because it is well established that dietary records are a poor indicator of sodium intake, such a study would require collection of all urine and sweat excreted over at least three days, since sweat sodium losses reduce urinary sodium excretion (Lichton 1957), and urinary sodium excretion is a poor predictor of intake unless collected for several consecutive days (Lerchl et al., 2015). This aspect of study design would be a major imposition on endurance athletes preparing for competition, and logistically challenging for researchers.

The current study demonstrated endurance athletes are more likely to seek information from fellow athletes, friends and family, the media and self-experimentation rather than health professionals, coaches or scientific literature. This is perhaps not surprising considering health professionals, coaches and scientific literature are less available and require increased time and financial commitment. Our findings are consistent with studies on information sources for other aspects of sports nutrition such as caffeine and fluid (Desbrow \& Leveritt, 2007; Winger et al., 2011; Winger et al., 2013). Unsurprisingly, professional and aspiring professional athletes were more likely to seek advice from health professionals and peer-reviewed journals, given their career relies on this advice to optimise performance, and in some cases, advice is provided at no cost through team or sponsorship arrangements. 
Many of the beliefs included in the questionnaire were not supported by scientific evidence, despite general agreement from participants. Statements with the highest agreement included sodium to improve endurance performance, prevent and/or attenuate EAMC and EAH. Evidence for sodium intake during exercise to improve performance (McCubbin \& Costa, 2018b), prevent or manage EAMC is scarce (Schwellnus, 2009), and the role of sodium in preventing EAH appears minimal in comparison to fluid intake management and/or behaviours (Hew-Butler et al., 2015). Given professional and aspiring professional athletes more readily consult health professionals, but did not have different beliefs about sodium, this suggests either health professionals are not providing athletes advice in accordance with current scientific literature, are referring to guidelines that do not reflect findings of individual studies (Hoffman, Bross, \& Hamilton, 2016), or athlete beliefs are more strongly influenced by other information sources, despite seeking information from qualified professionals.

Differences between sexes were minimal in the present study, except males were more likely to be influenced by non-scientific information sources and intended to consume more commercial sports nutrition products to obtain sodium compared to females. Whilst previous studies investigating beliefs and practices of sodium ingestion during exercise have included both male and female participants, we are unaware of any that have analysed the effect of sex in this way. There were also regional variations in our data, but in general most responses were remarkably similar. This may reflect commonality not only in language but sporting culture, marketing, food environment and access to sports nutrition information between Australia and New Zealand, the USA and Canada, and the UK and Ireland. These results should be interpreted with caution if extrapolating to countries with language, cultural and environmental differences.

Despite the strong belief amongst respondents that quantifying sodium losses was worthwhile, less than $5 \%$ reported doing so. This may reflect a lack of availability of sweat testing services, or that it is not prioritised amongst other factors during preparation for competition. In addition, despite $79 \%$ 
reporting being conscious of sodium intake during competition, only $29 \%$ could articulate a specific strategy for doing so. A lack of investment by endurance athletes in quantifying sodium losses and developing replacement strategies may also reflect the absence of evidence-based guidelines to support this practice (Thomas et al., 2016). Future research should investigate the effect of targeted sodium replacement strategies during endurance exercise on health and performance outcomes and the potential role, if any, of sweat composition testing in informing this strategy.

\section{Limitations}

There are several limitations to our study design, mainly relating to the methods used to obtain data from participants. The nature of recruitment for online questionnaires is likely to result in selfselection bias, whereby those with strong opinions on the topic of interest are most likely to complete the questionnaire (Khazaal et al., 2014). Whilst this is likely to have been the case here, we note great variance in responses regarding sodium beliefs, as well as demographic characteristics (age and competitive level) that closely align with previously published demographic information for competitors in ultramarathon (Hoffman \& Fogard, 2012) and Ironman and Ironman 70.3 triathlon events (World Triathlon Corporation, 2018). It is noted that females appear over-represented in our dataset compared to the number of entrants in endurance competitions, however the separate analysis of data by sex allows for meaningful comparisons to be made despite this discrepancy. In addition, self-selection bias is also likely to be prevalent in most other study designs within the field of sport and exercise nutrition, due to the time commitment, and in many cases inconvenience and/or potential discomfort of body fluid and tissue sampling. It is also acknowledged that the number of responses per region varied markedly, with only 28 responses from the UK and Ireland. Caution should be applied when interpreting differences by region and competitive level, although more similarities than differences were observed between sub-groups. Finally, despite the wide variability in responses, the nature of the questions means that respondents may be more likely to agree than disagree with any proposed statement (Lavrakas, 2008 ref). Therefore, care should be taken when interpreting sodium beliefs data, especially where the median value was close to $50 \%$. 


\section{Conclusion}

315 From analysis of 344 responses to an online questionnaire across six English-speaking countries, we

316 found endurance athletes commonly believe they have increased sodium needs before, during and after

317 training and competition. Many endurance athletes intend to deliberately increase sodium intake before 318 and during competition. These beliefs and intentions appear to be informed mostly by non-scientific

319 information sources, although it has been noted that reliance on sports nutrition guidelines may lead to 320 athletes receiving similar advice from health professionals. There remains a significant need for better 321 evidence to inform sodium intake guidelines, that outline (if deemed relevant) specific sodium intake 322 strategies to optimise performance and prevent adverse health outcomes in the short, or long-term for 323 endurance athletes. 
327 The authors thank Ben Desbrow from Griffith University for his insights and suggestions on study design, and the participants from around the world who took the time to complete the questionnaire. AM, GC and RC were involved in the study design. AM recruited participants, collected and analysed all data. Data interpretation and manuscript preparation were undertaken by AM, GC and RC. All authors approved the final version of the paper.

\section{Conflicts of interest}

All authors have no conflicts of interest to declare.

\section{References}

Baker, L. B. (2017). Sweating Rate and Sweat Sodium Concentration in Athletes: A Review of

Methodology and Intra/Interindividual Variability. Sports Medicine, 47(Suppl 1), 111-128.

Beasley, T. M., \& Schumacker, R. E. (1995). Multiple Regression Approach to Analyzing

Coles, M. G., \& Luetkemeier, M. J. (2005). Sodium-facilitated hypervolemia, endurance performance, and thermoregulation. International Journal of Sports Medicine, 26(3), 182-187. 
351 Costa, R. J., Teixeira, A., Rama, L., Swancott, A. J. M., Hardy, L. D., Lee, B., . . Thake, C. D.

352 (2013). Water and sodium intake habits and status of ultra-endurance runners during a multi-stage

353 ultra-marathon conducted in a hot ambient environment: an observational field based study. Nutrition

354 Journal, 12, 13.

355

356

Desbrow, B., \& Leveritt, M. (2007). Well-trained endurance athletes' knowledge, insight, and

experience of caffeine use. International Journal of Sport Nutrition and Exercise Metabolism, 17(4), 328-339.

359

Hew-Butler, T., Rosner, M. H., Fowkes-Godek, S., Dugas, J. P., Hoffman, M. D., Lewis, D. P., . . .

Verbalis, J. G. (2015). Statement of the 3rd International Exercise-Associated Hyponatremia

Consensus Development Conference, Carlsbad, California, 2015. British Journal of Sports Medicine, 49(22), 1432-1446.

Hew-Butler, T., Stuempfle, K. J., \& Hoffman, M. D. (2013). Bone: an acute buffer of plasma sodium during exhaustive exercise? Hormone and Metabolic Research, 45(10), 697-700.

Hoffman, M. D., \& Fogard, K. (2012). Demographic characteristics of 161-km ultramarathon runners. Research in Sports Medicine, 20(1), 59-69.

Hoffman, M. D., Hew-Butler, T., \& Stuempfle, K. J. (2013). Exercise-associated hyponatremia and hydration status in 161-kilometer ultramarathoners. Medicine and Science in Sports and Exercise, 45(4), 784-791.

Hoffman, M. D., \& Stuempfle, K. J. (2014). Hydration strategies, weight change and performance in a 
378

379

380

381

382

383

384

385

386

387

388

389

390

391

392

393

394

395

396

397

398

399

400

401

402

403

404

405

Hoffman, M.D., Bross, T.L., \& Hamilton, R.T. (2016). Are we being drowned by overhydration advice on the Internet? Phys Sportsmed, 44(4), 343-348.

Khazaal, Y., van Singer, M., Chatton, A., Achab, S., Zullio, D., Rothen, S., . . Thorens, G. (2014).

Does Self-Selection Affect Samples' Representativeness in Online Surveys? An Investigation in Online Video Game Research. Journal of Medical Internet Research, 16(7), e164.

\section{Lavrakas, P. J. (2008). Encyclopedia of survey research methods. Thousand Oaks, CA: SAGE}

\section{Publications Ltd doi: $10.4135 / 9781412963947$}

Lerchl, K., Rakova, N., Dahlmann, A., Rauh, M., Goller, U., Basner, M., Dinges, D.F., Beck, L., Agureev, A., Larina, I., Baranov, V., Morukov, B., Eckardt, K.U., Vassilieva, G., Wabel, P., Vienken, J., Kirsch, K., Johannes, B., Krannich, A., Luft, F.C., Titze, J. (2015). Agreement between 24-hour salt ingestion and sodium excretion in a controlled environment. Hypertension, 66(4), 850-857.

Lewis, D., Blow, A., Tye, J., \& Hew-Butler, T. (2018). Considering exercise-associated hyponatraemia as a continuum. BMJ Case Reports, 2018.

Lichton, I. J. (1957). Competition between sweat glands and kidneys for salt and water in man. Journal of Applied Physiology, 11(2), 223-226.

McCubbin, A. J., \& Costa, R. J. S. (2018a). Impact of Sodium Ingestion During Exercise on Endurance Performance: A Systematic Review. International Journal of Sports Science, 8(3), 97-107.

McCubbin, A. J., \& Costa, R. J. S. (2018b). The Impact of Dietary Sodium Intake on Sweat Sodium Concentration in Response to Endurance Exercise: A Systematic Review. International Journal of Sports Science, 8(1), 25-37. 
406 Noakes, T.D., Sharwood, K., Speedy, D., Hew, T., Reid, S., Dugas, J., Almond, C., Wharam, P., \&

407 Weschler, L. (2005). Three independent biological mechanisms cause exercise-associated

408 hyponatremia: Evidence from 2,135 weighed competitive athletic performances. PNAS, 102(51),

$409 \quad 18550-18555$.

410

411 Ogbogu, U., Necyk, C. (2016). Community Pharmacists' Views and Practices Regarding Natural

412 Health Products Sold in Community Pharmacies. PLoS One, 11(9), e0163450.

413

414 Pfeiffer, B., Stellingwerff, T., Hodgson, A. B., Randell, R., Pottgen, K., Res, P., \& Jeukendrup, A. E.

415 (2012). Nutritional intake and gastrointestinal problems during competitive endurance events.

416 Medicine and Science in Sports and Exercicse, 44(2), 344-351.

417

418 Sawka, M. N., Burke, L. M., Eichner, E. R., Maughan, R. J., Montain, S. J., \& Stachenfeld, N. S.

419 (2007). American College of Sports Medicine position stand. Exercise and fluid replacement.

420 Medicine and Science in Sports and Exercicse, 39(2), 377-390.

421

422 Schwellnus, M. P. (2009). Cause of exercise associated muscle cramps (EAMC)--altered

423 neuromuscular control, dehydration or electrolyte depletion? British Journal of Sports Medicine,

$424 \quad 43(6), 401-408$.

425

426

Shirreffs, S. M., \& Sawka, M. N. (2011). Fluid and electrolyte needs for training, competition, and recovery. Journal of Sports Sciences, 29 Suppl 1, S39-46.

428

Sims, S. T., Rehrer, N. J., Bell, M. L., \& Cotter, J. D. (2007). Preexercise sodium loading aids fluid balance and endurance for women exercising in the heat. Journal of Applied Physiology, 103(2), 534541. 
433

434

435

436

437

438

439

440

441

442

443

444

445

446

447

448

449

450

451

452

453

454

455

456

457

Thomas, D. T., Erdman, K. A., \& Burke, L. M. (2016). American College of Sports Medicine Joint

Position Statement. Nutrition and Athletic Performance. Medicine and Science in Sports and

Exercicse, 48(3), 543-568.

White, M. D., \& Hoffman, M. D. (2018). Beliefs of Ultramarathon Runners About Salt Tablets:

Findings From the Ultrarunners Longitudinal TRAcking (ULTRA) Study. International Journal of Sports Physiology and Performance, 13(S1), 6.

Winger, J. M., Dugas, J. P., \& Dugas, L. R. (2011). Beliefs about hydration and physiology drive drinking behaviours in runners. British Journal of Sports Medicine, 45(8), 646-649.

Winger, J. M., Hoffman, M. D., Hew-Butler, T. D., Stuempfle, K. J., Dugas, J. P., Fogard, K., \& Dugas, L. R. (2013). The Effect of Physiology and Hydration Beliefs on Race Behavior and Postrace Sodium in 161-km Ultramarathon Finishers. International Journal of Sports Physiology \& Performance, 8(5), 536-541.

World Triathlon Corporation (2018). The Average Ironman Athlete. In Ironman 2018 Media Guide (p. 20). Retrieved from http://ap.ironman.com/ /media/bd5edfa0991a49cf9788e786812a6d06/2018\%20ironman\%20mediagu ide\%2081618\%20sd\%20v5.pdf

Yoon, S.L., Grundmann, O., Smith, K.F., Mason, S.R. (2018). Dietary Supplement and Complementary and Alternative Medicine Use Are Highly Prevalent in Patients with Gastrointestinal Disorders: Results from an Online Survey. Journal of Dietary Supplements, 29 Jun, https://doi.org/10.1080/19390211.2018.1472712 
Table 1. Participant characteristics

\begin{tabular}{|c|c|c|c|c|c|c|c|c|c|c|c|c|}
\hline & \multicolumn{4}{|c|}{ Total } & \multicolumn{4}{|c|}{ Male } & \multicolumn{4}{|c|}{ Female } \\
\hline & $\begin{array}{l}\text { Australia/ } \\
\text { New } \\
\text { Zealand } \\
\end{array}$ & $\begin{array}{l}\text { USA/ } \\
\text { Canada }\end{array}$ & $\begin{array}{l}\text { UK/ } \\
\text { Ireland }\end{array}$ & Total & $\begin{array}{c}\text { Australia/ } \\
\text { New } \\
\text { Zealand } \\
\end{array}$ & $\begin{array}{l}\text { USA/ } \\
\text { Canada }\end{array}$ & $\begin{array}{l}\text { UK/ } \\
\text { Ireland }\end{array}$ & Total & $\begin{array}{c}\text { Australia/ } \\
\text { New } \\
\text { Zealand } \\
\end{array}$ & $\begin{array}{l}\text { USA/ } \\
\text { Canada }\end{array}$ & $\begin{array}{l}\text { UK/ } \\
\text { Ireland }\end{array}$ & Total \\
\hline $\begin{array}{l}\text { Number of } \\
\text { participants (n) }\end{array}$ & 219 & 97 & 28 & 344 & 136 & 50 & 13 & 199 & 83 & 47 & 15 & 145 \\
\hline Age (median (IQR)) & $43(14)$ & $39(18)$ & $42(9.5)$ & $42(15)$ & $43(14)$ & $39(18)$ & $42(9.5)$ & $43(16)$ & $43(11.5)$ & $36(14)$ & $40(10)$ & $40(14)$ \\
\hline $\begin{array}{l}\text { Years competing } \\
\text { (median }(I Q R))\end{array}$ & $6(8)$ & $12(14)$ & $8(8)$ & $8(11)$ & $7(11)$ & $14.5(19.25)$ & $8(12)$ & $10(14)$ & $5(7)$ & $10(10)$ & $8(7)$ & $7(8)$ \\
\hline $\begin{array}{c}\text { Competitive Level: } \\
\text { Professional }\end{array}$ & $0.9 \%$ & $4.1 \%$ & $0.0 \%$ & $1.7 \%$ & $0.0 \%$ & $4.0 \%$ & $0.0 \%$ & $1.0 \%$ & $2.4 \%$ & $4.3 \%$ & $0.0 \%$ & $2.8 \%$ \\
\hline $\begin{array}{l}\text { Aspiring } \\
\text { Professional }\end{array}$ & $4.1 \%$ & $5.2 \%$ & $10.7 \%$ & $4.9 \%$ & $4.4 \%$ & $8.0 \%$ & $15.4 \%$ & $6.0 \%$ & $3.6 \%$ & $2.1 \%$ & $6.7 \%$ & $3.4 \%$ \\
\hline $\begin{array}{l}\text { Competitive } \\
\text { age-group } \\
\text { athlete }\end{array}$ & $65.3 \%$ & $73.2 \%$ & $42.9 \%$ & $65.7 \%$ & $72.1 \%$ & $80.0 \%$ & $46.2 \%$ & $72.4 \%$ & $54.2 \%$ & $66.0 \%$ & $40.0 \%$ & $56.6 \%$ \\
\hline $\begin{array}{l}\text { Training } \\
\text { regularly for } \\
\text { health \& fitness }\end{array}$ & $28.8 \%$ & $16.5 \%$ & $46.4 \%$ & $26.7 \%$ & $22.1 \%$ & $8.0 \%$ & $38.5 \%$ & $19.6 \%$ & $39.8 \%$ & $25.5 \%$ & $53.3 \%$ & $36.6 \%$ \\
\hline $\begin{array}{l}\text { Training } \\
\text { irregularly for } \\
\text { health \& fitness }\end{array}$ & $0.9 \%$ & $1.0 \%$ & $0.0 \%$ & $0.9 \%$ & $1.5 \%$ & $0.0 \%$ & $0.0 \%$ & $1.0 \%$ & $0.0 \%$ & $2.1 \%$ & $0.0 \%$ & $0.7 \%$ \\
\hline Event participation: & & & & & & & & & & & & \\
\hline $\begin{array}{l}\text { Events }<3 \text { h or } \\
\text { less than } \\
\text { marathon or } \\
\text { Olympic } \\
\text { distance } \\
\text { (running and } \\
\text { triathlon) }\end{array}$ & $16.4 \%$ & $27.8 \%$ & $32.1 \%$ & $20.9 \%$ & $11.0 \%$ & $16.0 \%$ & $15.4 \%$ & $12.6 \%$ & $25.3 \%$ & $40.4 \%$ & $46.7 \%$ & $32.4 \%$ \\
\hline $\begin{array}{l}\text { Events }>3 \text { h or } \\
\text { greater than } \\
\text { marathon or } \\
\text { Olympic } \\
\text { distance } \\
\text { (running and } \\
\text { triathlon) }\end{array}$ & $83.6 \%$ & $72.2 \%$ & $67.9 \%$ & $79.1 \%$ & $89.0 \%$ & $84.0 \%$ & $84.6 \%$ & $87.4 \%$ & $74.7 \%$ & $59.6 \%$ & $53.3 \%$ & $67.6 \%$ \\
\hline
\end{tabular}


Table 2. Sources of information about sodium consumption before, during and after endurance exercise by sex, region and performance level

\begin{tabular}{|c|c|c|c|c|c|c|c|c|c|c|c|c|}
\hline & Total & $\begin{array}{c}\text { Australia/ } \\
\text { New Zealand }\end{array}$ & $\begin{array}{c}\text { USA/ } \\
\text { Canada }\end{array}$ & $\begin{array}{c}U K / \\
\text { Ireland }\end{array}$ & $\begin{array}{c}\text { Association } \\
\text { between region and } \\
\text { information source } \\
\chi^{2}(p)\end{array}$ & Male & Female & $\begin{array}{c}\text { Association between } \\
\text { sex and information } \\
\text { source } \chi^{2}(p)\end{array}$ & $\begin{array}{l}\text { Health and } \\
\text { Fitness }\end{array}$ & $\begin{array}{l}\text { Competitive } \\
\text { Age Group }\end{array}$ & $\begin{array}{c}\text { Professional/ } \\
\text { aspiring } \\
\text { professional }\end{array}$ & $\begin{array}{c}\text { Association } \\
\text { between training } \\
\text { level and } \\
\text { information } \\
\text { source } \chi^{2}(p)\end{array}$ \\
\hline $\begin{array}{l}\text { Number of } \\
\text { participants (n) }\end{array}$ & 344 & 219 & 97 & 28 & & 199 & 145 & & 95 & 226 & 23 & \\
\hline $\begin{array}{l}\text { Never } \\
\text { considered the } \\
\text { use of sodium } \\
\text { with sport }\end{array}$ & $8.1 \%$ & $10.0 \%$ & $3.1 \%$ & $10.7 \%$ & $4.3(0.117)$ & $7.0 \%$ & $9.7 \%$ & $0.8(0.380)$ & $9.5 \%$ & $7.5 \%$ & $8.7 \%$ & $0.4(0.839)$ \\
\hline $\begin{array}{l}\text { Health } \\
\text { Professionals }\end{array}$ & $37.8 \%$ & $37.9 \%$ & $43.3 \%$ & $17.9 \%$ ab & $6.0(0.05)$ & $35.7 \%$ & $40.7 \%$ & $0.9(0.344)$ & $30.5 \%$ & $38.5 \%$ & $60.9 \%$ cd & $7.4(0.025)$ \\
\hline $\begin{array}{l}\text { Sport-specific } \\
\text { supports }\end{array}$ & $34.6 \%$ & $36.1 \%$ & $39.2 \%$ & $7.1 \%$ ab & $10.5(0.005)$ & $32.7 \%$ & $37.2 \%$ & $0.8(0.378)$ & $31.6 \%$ & $35.0 \%$ & $43.5 \%$ & $1.2(0.550)$ \\
\hline Social supports & $63.4 \%$ & $63.0 \%$ & $69.1 \%$ & $46.4 \%$ & $4.8(0.09)$ & $61.3 \%$ & $66.2 \%$ & $0.9(0.352)$ & $58.9 \%$ & $65.9 \%$ & $56.5 \%$ & $1.9(0.386)$ \\
\hline $\begin{array}{l}\text { Peer reviewed } \\
\text { journals }\end{array}$ & $29.7 \%$ & $27.4 \%$ & $32.0 \%$ & $39.3 \%$ & $2.0(0.375)$ & $32.2 \%$ & $26.2 \%$ & $1.4(0.232)$ & $21.1 \%$ & $31.4 \%$ & $47.8 \%^{\mathrm{c}}$ & $7.3(0.025)$ \\
\hline Media & $48.0 \%$ & $42.5 \%$ & $51.5 \%$ & $78.6 \%$ ab & $13.5(0.001)$ & $53.3 \%$ & $40.7 \%$ & $5.3(0.021)$ & $46.3 \%$ & $50.4 \%$ & $30.4 \%$ & $3.5(0.175)$ \\
\hline $\begin{array}{l}\text { Sales \& } \\
\text { Marketing }\end{array}$ & $21.5 \%$ & $21.5 \%$ & $21.6 \%$ & $21.4 \%$ & $0.001(1.000)$ & $22.6 \%$ & $20.0 \%$ & $0.3(0.560)$ & $15.8 \%$ & $23.0 \%$ & $30.4 \%$ & $3.2(0.199)$ \\
\hline $\begin{array}{l}\text { Self- } \\
\text { experimentation }\end{array}$ & $55.8 \%$ & $55.7 \%$ & $57.7 \%$ & $50.0 \%$ & $0.5(0.768)$ & $57.3 \%$ & $53.8 \%$ & $0.4(0.519)$ & $49.5 \%$ & $58.8 \%$ & $51.2 \%$ & $2.5(0.284)$ \\
\hline
\end{tabular}

462 a Significantly different from Australia/New Zealand $(\mathrm{p}<0.05),{ }^{\mathrm{b}}$ significantly different from USA/Canada $(\mathrm{p}<0.05)$, ${ }^{\mathrm{c}}$ significantly different from Health

463 and Fitness $(p<0.05),{ }^{d}$ significantly different from Competitive Age Group $(p<0.05)$. 
465 Table 3: Foods chosen for their sodium content in the days prior to competition.

466

\begin{tabular}{|c|c|c|c|c|c|c|c|c|c|c|c|c|}
\hline & Total & $\begin{array}{c}\text { Australia/ } \\
\text { New Zealand }\end{array}$ & $\begin{array}{c}\text { USA } \\
\text { Canada }\end{array}$ & $\begin{array}{l}\text { UK/ } \\
\text { Ireland }\end{array}$ & $\begin{array}{c}\text { Association } \\
\text { between region and } \\
\text { food choice } \chi^{2}(p)\end{array}$ & Male & Female & $\begin{array}{c}\text { Association between } \\
\text { sex and food choice } \\
\qquad \chi^{2}(p)\end{array}$ & $\begin{array}{l}\text { Health and } \\
\text { Fitness }\end{array}$ & $\begin{array}{l}\text { Competitive } \\
\text { Age Group }\end{array}$ & $\begin{array}{l}\text { Professional } \\
\text { aspiring } \\
\text { professional }\end{array}$ & $\begin{array}{c}\text { Association } \\
\text { between training } \\
\text { level and food } \\
\text { choice } \chi^{2}(p) \\
\end{array}$ \\
\hline $\begin{array}{l}\text { Number of } \\
\text { participants (n) }\end{array}$ & 151 & 93 & 43 & 15 & & 88 & 63 & & 35 & 101 & 15 & \\
\hline $\begin{array}{l}\text { Regular foods } \\
\text { high in sodium }\end{array}$ & $32.5 \%$ & $28.0 \%$ & $37.2 \%$ & $46.7 \%$ & $2.7(0.261)$ & $25.0 \%$ & $42.9 \%$ & $5.3(0.021)$ & $25.7 \%$ & $36.6 \%$ & $20 \%$ & $2.6(0.274)$ \\
\hline $\begin{array}{l}\text { Added salt to } \\
\text { food and fluids }\end{array}$ & $40.4 \%$ & $32.3 \%$ & $55.8 \%{ }^{\mathrm{a}}$ & $46.7 \%^{\mathrm{a}}$ & $7.0(0.029)$ & $34.1 \%$ & $49.2 \%$ & $3.5(0.062)$ & $31.4 \%$ & $43.6 \%$ & $40.0 \%$ & $1.6(0.451)$ \\
\hline $\begin{array}{l}\text { Sports, } \\
\text { rehydration and } \\
\text { electrolyte } \\
\text { drinks (ready to } \\
\text { drink) }\end{array}$ & $24.5 \%$ & $20.4 \%$ & $34.9 \%$ & $20.0 \%$ & $3.5(0.174)$ & $21.6 \%$ & $28.6 \%$ & $1.0(0.325)$ & $31.4 \%$ & $24.8 \%$ & $6.7 \%$ & $3.5(0.175)$ \\
\hline $\begin{array}{l}\text { Sports, } \\
\text { rehydration and } \\
\text { electrolyte } \\
\text { drinks (made } \\
\text { from powder) }\end{array}$ & $41.1 \%$ & $40.9 \%$ & $48.8 \%$ & $20.0 \%$ & $3.8(0.148)$ & $48.9 \%$ & $30.2 \%$ & $5.3(0.021)$ & $31.4 \%$ & $42.6 \%$ & $53.3 \%$ & $2.4(0.306)$ \\
\hline $\begin{array}{l}\text { Sports, } \\
\text { rehydration and } \\
\text { electrolyte } \\
\text { drinks } \\
\text { (dissolvable } \\
\text { tablets) }\end{array}$ & $37.7 \%$ & $36.6 \%$ & $37.2 \%$ & $46.7 \%$ & $0.6(0.752)$ & $34.1 \%$ & $42.9 \%$ & $1.2(0.273)$ & $37.1 \%$ & $34.7 \%$ & $60.0 \%$ & $3.6(0.167)$ \\
\hline $\begin{array}{l}\text { Salt or } \\
\text { electrolyte } \\
\text { tablets or } \\
\text { capsules }\end{array}$ & $28.5 \%$ & $28.0 \%$ & $34.9 \%$ & $13.3 \%$ & $2.6(0.277)$ & $30.7 \%$ & $25.4 \%$ & $0.5(0.478)$ & $28.6 \%$ & $26.7 \%$ & $40.0 \%$ & $1.1(0.569)$ \\
\hline
\end{tabular}

$467{ }^{a}$ Significantly different from Australia/New Zealand $(\mathrm{p}<0.05)$, ${ }^{\mathrm{b}}$ significantly different from USA/Canada $(\mathrm{p}<0.05)$, ${ }^{\mathrm{c}}$ significantly different from Health

468 and Fitness $(\mathrm{p}<0.05)$, ${ }^{\mathrm{d}}$ significantly different from Competitive Age Group $(\mathrm{p}<0.05)$. 
469 Table 4: Foods chosen for their sodium content during competition

\begin{tabular}{|c|c|c|c|c|c|c|c|c|c|c|c|c|}
\hline & Total & $\begin{array}{c}\text { Australia/ } \\
\text { New } \\
\text { Zealand }\end{array}$ & $\begin{array}{c}\text { USA } \\
\text { Canada }\end{array}$ & $\begin{array}{c}\text { UK/ } \\
\text { Ireland }\end{array}$ & $\begin{array}{c}\text { Association } \\
\text { between region and } \\
\text { food choice } \chi^{2}(p)\end{array}$ & Male & Female & $\begin{array}{c}\text { Association between } \\
\text { sex and food choice } \\
\qquad \chi^{2}(p)\end{array}$ & $\begin{array}{l}\text { Health and } \\
\text { Fitness }\end{array}$ & $\begin{array}{l}\text { Competitive } \\
\text { Age Group }\end{array}$ & $\begin{array}{l}\text { Professional/ } \\
\text { aspiring } \\
\text { professional }\end{array}$ & $\begin{array}{c}\text { Association } \\
\text { between training } \\
\text { level and food } \\
\text { choice } \chi^{2}(p) \\
\end{array}$ \\
\hline $\begin{array}{l}\text { Number of } \\
\text { participants (n) }\end{array}$ & 344 & 219 & 97 & 28 & & 199 & 145 & & 95 & 226 & 23 & \\
\hline Sports Drinks & $57.8 \%$ & $55.3 \%$ & $67.0 \%$ & $46.4 \%$ & $5.3(0.070)$ & $57.8 \%$ & $57.9 \%$ & $0.001(0.979)$ & $60.0 \%$ & $57.5 \%$ & $52.2 \%$ & $0.5(0.781)$ \\
\hline $\begin{array}{l}\text { Rehydration } \\
\text { Drinks }\end{array}$ & $28.5 \%$ & $33.8 \%$ & $20.6 \%$ a & $14.3^{\circ}$ & $8.9(0.012)$ & $31.2 \%$ & $24.8 \%$ & $1.6(0.199)$ & $31.6 \%$ & $27.4 \%$ & $26.1 \%$ & $0.6(0.728)$ \\
\hline $\begin{array}{l}\text { Electrolyte } \\
\text { capsules and } \\
\text { tablets }\end{array}$ & $50.9 \%$ & $50.7 \%$ & $51.5 \%$ & $50.0 \%$ & $0.02(0.988)$ & $50.3 \%$ & $51.7 \%$ & $0.07(0.787)$ & $48.4 \%$ & $52.2 \%$ & $47.8 \%$ & $0.5(0.788)$ \\
\hline Energy Gels & $67.7 \%$ & $68.5 \%$ & $69.1 \%$ & $57.1 \%$ & $1.6(0.461)$ & $67.8 \%$ & $67.6 \%$ & $0.002(0.960)$ & $62.1 \%$ & $69.5 \%$ & $73.9 \%$ & $2.1(0.352)$ \\
\hline $\begin{array}{l}\text { Energy } \\
\text { bars/chews/foods }\end{array}$ & $41.9 \%$ & $42.0 \%$ & $44.3 \%$ & $32.1 \%$ & $1.3(0.515)$ & $47.2 \%$ & $34.5 \%$ & $5.6(0.018)$ & $46.3 \%$ & $40.3 \%$ & $39.1 \%$ & $1.1(0.582)$ \\
\hline Vegemite & $8.4 \%$ & $12.8 \%$ & $0.0 \%^{\mathrm{a}}$ & $3.6 \%{ }^{a}$ & $15.2(<0.001)$ & $6.0 \%$ & $11.7 \%$ & $3.5(0.061)$ & $14.7 \%$ & $6.2 \%^{\mathrm{c}}$ & $4.3 \%$ & $6.9(0.032)$ \\
\hline $\begin{array}{l}\text { Homemade, } \\
\text { savoury snacks \& } \\
\text { coconut water }\end{array}$ & $12.8 \%$ & $13.7 \%$ & $11.3 \%$ & $10.7 \%$ & $0.5(0.789)$ & $12.1 \%$ & $13.8 \%$ & $0.3(0.635)$ & $15.8 \%$ & $11.9 \%$ & $8.7 \%$ & $1.3(0.534)$ \\
\hline
\end{tabular}

470 a Significantly different from Australia/New Zealand $(\mathrm{p}<0.05),{ }^{\mathrm{b}}$ significantly different from USA/Canada $(\mathrm{p}<0.05),{ }^{\mathrm{c}}$ significantly different from Health

471 and Fitness $(p<0.05),{ }^{d}$ significantly different from Competitive Age Group $(p<0.05)$. 


\section{$472 \quad$ Figure Legends}

473

474 Figure 1. Level of agreement of endurance athletes regarding aspects of sodium intake and sweat

475 sodium measurement for training and competition. Level of agreement is scored on a Visual Analogue

476 Scale (VAS), where 50\% indicates neither agreement nor disagreement with the stated effect.

477

478 Figure 2. Level of agreement of endurance athletes regarding the effect of sodium intake during

479 endurance exercise on aspects of physiological function and health outcomes. Level of agreement is

480 scored on a Visual Analogue Scale (VAS), where 50\% indicates neither agreement nor disagreement

481 with the stated effect. EAMC: exercise-associated muscle cramps, EAH: exercise-associated

482 hyponatraemia, BMC: bone mineral content. 


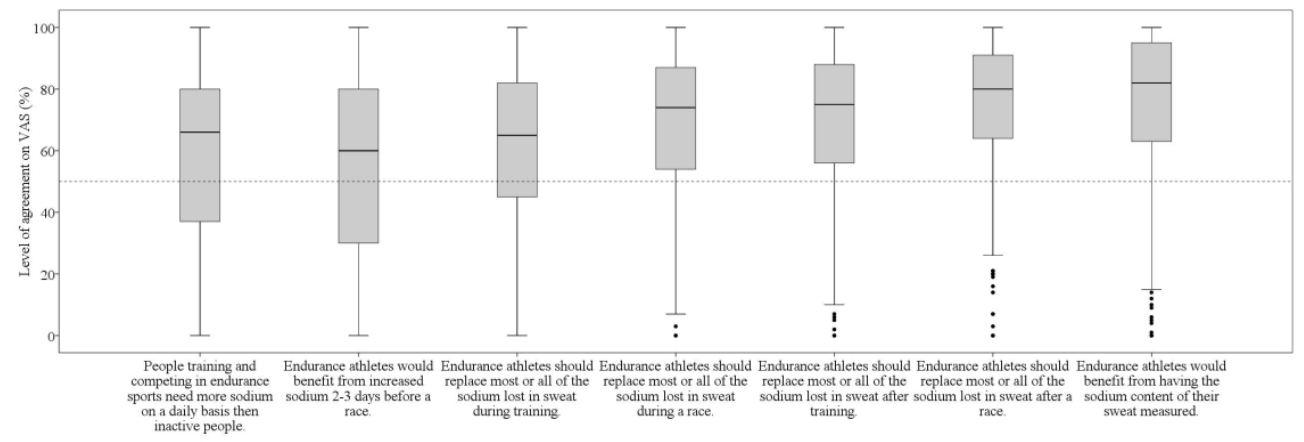

Figure 1. Level of agreement of endurance athletes regarding aspects of sodium intake and sweat sodium measurement for training and competition. Level of agreement is scored on a Visual Analogue Scale (VAS), where $50 \%$ indicates neither agreement nor disagreement with the stated effect.

$893 \times 317 \mathrm{~mm}(72 \times 72 \mathrm{DPI})$ 


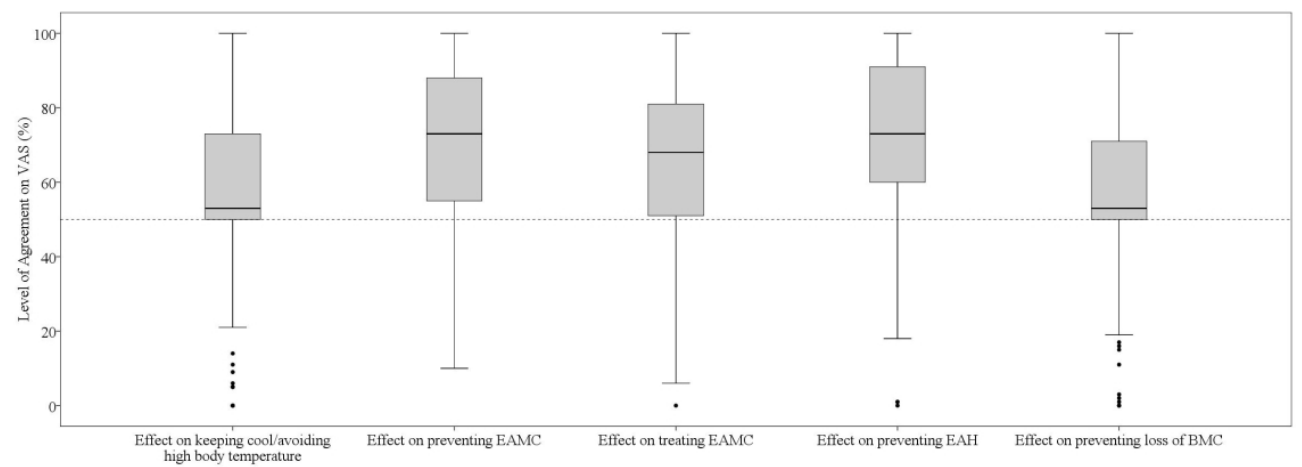

Figure 2. Level of agreement of endurance athletes regarding the effect of sodium intake during endurance exercise on aspects of physiological function and health outcomes. Level of agreement is scored on a Visual Analogue Scale (VAS), where $50 \%$ indicates neither agreement nor disagreement with the stated effect. EAMC: exercise-associated muscle cramps, EAH: exercise-associated hyponatraemia, BMC: bone mineral content.

$847 \times 301 \mathrm{~mm}(72 \times 72 \mathrm{DPI})$ 
1 Supplementary Appendix - Endurance Athlete Questionnaire

2

3 Demographics

$4 \quad$ Q1 What is your sex? $\square$ Male $\quad \square$ Female

5

$6 \quad$ Q2 What is your age in years?

7

8 Q3 Which sport/sports do you currently train and compete in?

9

10 Q4 For how many years have you been competing in endurance sports?

12 Q5 How would you best describe yourself and your level of training?

$13 \square$ Professional athlete, training regularly

$14 \square$ Aspiring professional athlete, training regularly

$15 \square$ Actively competitive age group athlete, training regularly

$16 \square$ Interest in general health and fitness, training regularly

$17 \square$ Interest in general health and fitness, training sometimes

19 Sodium Information Sources

20 Q26 From the following list, please select any individual(s) or information sources that have

21 influenced whether you choose/do not choose to consume a certain amount of sodium or sodium-

22 containing products relating to your endurance training or competition (please tick all responses that

23 apply to you - more than one answer is allowed). 
Other

\section{$35 \quad$ Sodium Beliefs}

36 Please click and drag the sliders to indicate how much you agree with each of the following

37 statements:

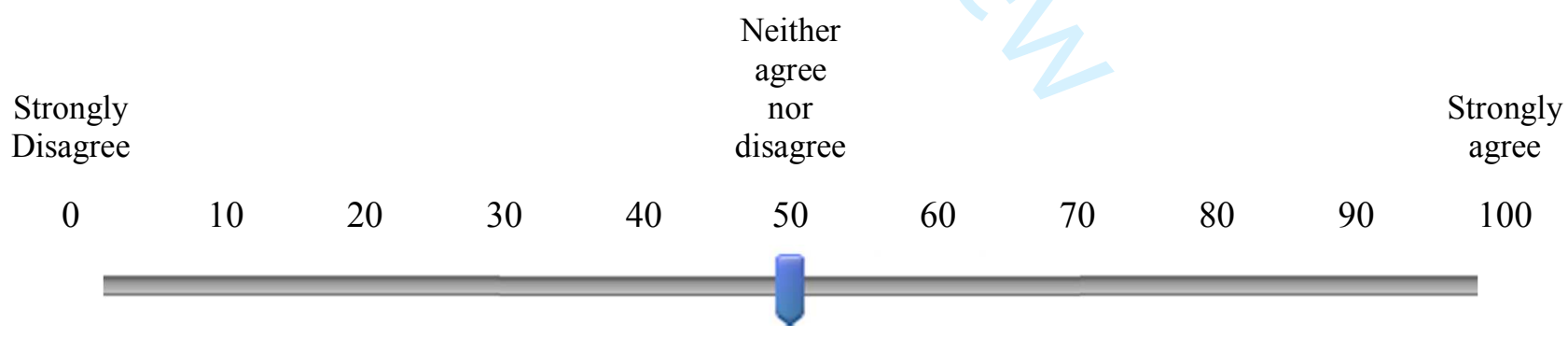

38 Q6 People training and competing in endurance sports need to eat more salt/sodium/electrolytes on a

39 day-to-day basis compared to people who are not exercising. 
41 Q7 Endurance sport competitors would benefit from increasing the amount of salt/sodium they

42 consume in the 2-3 days before a race.

43

44 Q8 During training, endurance athletes should aim to replace most or all of the salt/sodium lost in 45 sweat.

46

47 Q9 During a race, endurance athletes should aim to replace most or all of the salt/sodium lost in 48 sweat.

49

50 Q10 After training, endurance athletes should aim to replace most or all of the salt/sodium lost in 51 sweat.

52

53 Q12 After a race, endurance athletes should aim to replace most or all of the salt/sodium lost in sweat.

54

55 Q13 Endurance athletes would benefit from having the amount of sodium measured in their sweat.

56

57 If you were to specifically increase the amount of salt/sodium you consume on a day-to-day basis in

58 training (compare to a period of time when you are not training), what effect do YOU THINK it would

59 have on the following aspects of exercise performance? Click and drag the sliders to indicate your

60 response:

61

62

63 


\begin{tabular}{|c|c|c|c|c|c|c|c|c|c|c|}
\hline $\begin{array}{c}\text { Strong } \\
\text { negative } \\
\text { effect }\end{array}$ & & & & & $\begin{array}{l}\text { No } \\
\text { effec }\end{array}$ & & & & & $\begin{array}{l}\text { Strong } \\
\text { positive } \\
\text { effect }\end{array}$ \\
\hline 0 & 10 & 20 & 30 & 40 & 50 & 60 & 70 & 80 & 90 & 100 \\
\hline
\end{tabular}

64 Q14 Endurance during exercise of more than 1 hour

65

66 Q15 Speed in exercise of more than 1 hour

67

68 Q16 Power in exercise of more than 1 hour

69

70 Q17 Concentration/alertness

71

72 Q18 Keeping cool or avoiding high body temperature

73

74 Q19 Preventing muscle cramping during exercise

75

76 Q20 Reducing the severity of muscle cramping once it has started

77

78 Q21 Preventing hyponatraemia (low blood sodium) during exercise

79

80 Q22 Preventing loss of bone minerals during exercise

81 


\section{$82 \quad$ Intended Practices}

83 The following questions are about your use of sodium in the days and hours leading up to an

84 endurance race or competition. If you do not consciously focus on the amount of sodium in the days

85 or hours before competition, answer no to the first question and skip ahead to the next section.

86

87 Q27 In the days leading up to a race (that will have a duration of more than 2 hours), would you be 88 aware of consuming a certain amount of salt/sodium from food, fluids or supplements?

$89 \square$ Yes $\square$ No

$90 \square$ Sometimes (please provide comments)

91

92 Q28 Would you plan to eat more, less or the same amount of salt/sodium in the days leading up to a 93 race compared to day-to-day when you are training?

$94 \square$ I would plan to consume MORE sodium in the days before a race compared to when I'm training

$95 \square$ I would plan to consume LESS sodium in the days before a race compared to when I'm training

$96 \square$ I would plan to consume THE SAME AMOUNT of sodium in the days before a race compared to 97 when I'm training

99 Q29 How long before a race (that will have a duration of more than 2 hours) would you be aware of 100 consuming a certain amount of sodium from food, fluids or supplements (answer can be in hours, 101 days or weeks)? 
104 Q30 What foods, drinks or supplements do you plan to consume to increase the amount of salt/sodium

105 in the lead up to a race? (can choose more than one)

$106 \square$ Eat more regular foods that are higher in salt/sodium

$107 \square$ Adding salt (table salt, sea salt, rock salt, etc.) to food/drinks

$108 \square$ Sports, rehydration or other electrolyte drinks (bottled)

$109 \square$ Sports, rehydration or other electrolyte drinks (made from powder)

$110 \square$ Sports, rehydration or other electrolyte drinks (dissolvable tablets)

$111 \square$ Salt/electrolyte capsules or tablets

$112 \square$ Other - please specify:

114 Q31 Regardless of sodium, would the overall amount of food you plan to eat change in the days

115 leading in to an endurance race or competition, compared to your day-to-day diet in training?

$116 \square$ I would eat MORE food overall

$117 \square$ I would eat LESS food overall

$118 \square$ I would eat about THE SAME amount of food overall

This section relates to your consumption of sodium/salt DURING competition

122 Q32 DURING a race (that will have a duration of more than 2 hours), would you be aware of 123 consuming sodium from food, fluids or supplements? 
127 Q33 How much sodium would you aim to take (can answer in milligrams (mg) OR amounts of certain

128 foods and drinks OR based on a percentage of expected losses)?

$129 \square$ Specify amount here OR

I'm not sure

131

132 Q34 Please tick all of the sodium-containing products you are planning to consume immediately

133 before and during your next race/event

$134 \square$ The sports drink provided by the race organisers

$135 \square$ The gels provided by the race organisers

$136 \square$ The energy bars/chews provided by the race organisers

$137 \square$ My own sports drink (sold as a sports product, not a rehydration product)

$138 \square$ My own rehydration drink (sold as a rehydration formula, not a sports product)

$139 \square$ My own dissolvable electrolyte tablets

$140 \square$ Salt or electrolyte tablets/capsules

$141 \square$ My own homemade drink formula (please provide details if possible)

$142 \square$ Energy gels I purchased myself

Energy bars/chews I purchased myself 
$145 \square$ Vegemite sandwich

$146 \square$ Other

148 Commercial Sweat Testing Experiences

149 Q35 Have you PREVIOUSLY had your sweat tested to measure the amount of

150 salt/sodium/electrolytes in it (not including research studies)?

$151 \square$ Yes $\square$ No

152

153 Q36 If yes, what was your main goal or motivation for having your sweat tested (can choose more 154 than 1 answer)?

$155 \square$ To improve my performance in training and/or competition

$156 \square$ To reduce the risk of muscle cramping during training and/or competition

$157 \square$ To reduce the risk of hyponatraemia during training and/or competition

$158 \square$ Other:

159

160 Q37 Do you feel that the results of your sweat test allowed you to better reach the goal/s stated in 161 question 24 (above)?

162
$\square$ Yes
$\square$ No
Not Sure 